\title{
Phytoremediation of Physico-chemical Parameters in Wastewater Effluents from Car Wash Bays in Yenagoa Metropolis, Nigeria
}

\author{
R. Alexander Bekeowei and Odafivwotu Ohwo
}

\section{ABSTRACT}

\begin{abstract}
Surface water pollution through the discharge of untreated wastewater is on the increase globally. Efforts made using conventional techniques had not yielded the needed results. This study was conducted to determine the effectiveness of some native aquatic plants for the removal of some physicochemical parameters from car wash wastewater effluents in Yenagoa metropolis. The plants used for this study were lemna minor, nymphaea nouchalli, pistia-stratiotes, eichhornia crassipes and ceratophyllum demersum; while the physico-chemical parameters investigated in this study include $\mathrm{pH}$, $\mathrm{DO}, \mathrm{COD}, \mathrm{BOD}_{5}, \mathrm{NO}_{3}, \mathrm{PO}_{4}$ and turbidity. The wastewater samples collected from car wash bays were analysed to determine the level of the physicochemical parameters concentrations using standard methods. The experiment was conducted in a green house for 42 days retention period. The results indicated that the cultured plants reduced the physico-chemical parameters to a minimum level, except DO, which increased in concentration. Therefore, they are considered good bioremediators of the parameters under review and the bioremediation potentials of the plants are in the order of $P$. stratiotes $>L$. minor $>E$. crassipes $>N$. nouchalli> $C$. demersum. It is therefore recommended that these plants should be used to treat wastewater effluents based on the investigated physico-chemical parameters.
\end{abstract}

Keywords: Aquatic Macrophytes, Physico-chemical Parameters, Phytoremediation, Wastewater.
Published Online: December 07,2021 ISSN: 2684-446X

DOI :10.24018/ejgeo.2021.2.6.212

\section{R. A. Bekeowei}

Department of Geography and Environmental Management, Niger Delta University, Wilberforce Island, Bayelsa State, Nigeria.

(e-mail: bekeokoroalex@gmail.com) O. Ohwo*

Department of Geography and Environmental Management, Niger Delta University, Wilberforce Island, Bayelsa State, Nigeria.

(e-mail: drohwodafe@gmail.com)

\section{INTRODUCTION}

The major route of pollutants to aquatic ecosystems in urban areas is through surface runoff and atmospheric deposition; other sources are from municipal and industrial discharges [1]. The cost of providing wastewater treatment plant has been a major barrier for the provision or installation of conventional treatment technologies in many developing countries. On this premise, the development of aquatic macrophytes-based wastewater treatment system is now recognized as suitable, cost effective and environment friendly [2].

The issue of water scarcity has been a nagging problem all over the world and in many developing countries the issue has become more challenging with the passage of each year. The issue becomes more worrisome considering the high level of surface water pollution globally [3]. The discharge of untreated wastewater into surface water bodies such as lakes, rivers, ponds, and streams make the water unsuitable for human consumption and may affect domestic and industrial uses. The main reasons for the increasing amount of wastewater in the environment are increase in population, urbanization, and industrialization, which have led to the pollution of water bodies [4]. Domestic and industrial discharges are the most important anthropogenic contaminants in the water environment [5]. Reference [6] asserted that wastewater is rarely treated to acceptable standards before discharge into the aquatic ecosystem, thereby polluting the natural environment by heavy metals, pesticides, fertilizers, among others, which pose serious threat to humans, animals, and plants [7].

In the Niger Delta region of Nigeria, several fresh water bodies abound including rivers, ponds, lakes, streams and creeks. These water bodies serve as waste disposal ground for most municipal waste especially in the coastal areas of Bayelsa State. These wastes depending on the source may contain several substances that could alter water quality parameters including microbial counts, heavy metals and physico-chemical properties. These wastes discharged into the water bodies may also provide nutrients that would promote the growth of different aquatic weeds found in the water [8]. The water bodies also serve as a medium for cleaning and disposal of untreated or poorly treated wastewater from different industries.

In recent times, there has been a tremendous population growth in Yenagoa metropolis. The exponential growth in urbanization through migration of people from rural, semi- 
urban and other urban areas to Yenagoa in search of livelihood, had contributed to the rapid increase in waste generation and discharge of solid waste and untreated wastewater into the environment. Although Yenagoa metropolis is not yet industrialized, however, there are some industries and other anthropogenic activities that are generating a lot of wastes, which contain both nutrient pollutants and heavy metals. Such industries include paint manufacturing industry, car wash industry and automotive spray paint industry, among others. Untreated wastes from these sources when discharged into the aquatic environment constitute serious environmental menace to the ecosystem.

Studies have revealed that car wash activities consume large amount of water and involve the release of different harmful chemicals into the environment during their cleaning operations [9]. Hence, car wash is a major source of water pollution [10]. For example, [11] asserted that wastewater effluents from car wash bays contain various types of pollutants (hydrocarbon, nutrients \& heavy metals), and the release of such contaminated wastewater effluents into the aquatic environment may degrade the water quality and destroy aquatic lives since the aquatic ecosystems provide varieties of habitat for many plants and animals species [12].

In addition, the use of different kinds of soaps and detergents at the car wash bays also accumulate phosphate load in the aquatic ecosystem that can result to eutrophication [13], and the subsequent reduction in dissolved oxygen (DO) concentration, which is an important requirement for the sustenance of any aquatic life. Unfortunately, less than eight per cent of both domestic and industrial wastewater effluents are treated in developing countries due to high cost of facilities provision [14].

In spite of this situation, the exponential increase of car wash service centres in the surrounding environment has resulted to tremendous increase in the level of pollution of freshwater bodies. Since freshwater ecosystem is a limited resource, it is imperative to manage it sustainably. However, the conventional wastewater treatment technologies are very expensive, not eco-friendly and are associated with secondary pollution [15]. Therefore, the use of aquatic macrophytesbased wastewater treatment is now recognized as less costly, eco-friendly, and devoid of secondary pollution; hence, it is being imbibed by many countries of the world [2]. Although there are many native aquatic plants used for the remediation of aquatic ecosystem degraded by contaminants, however, it is not clear which of them is the most effective. Hence, this study was designed to determine the potentials of some native aquatic plants for the removal of selected physico-chemical parameters in wastewater discharged into the aquatic ecosystem in Yenagoa metropolis.

\section{MATERIALS AND METHODS}

\section{A. The Study Area}

The study area is Yenagoa, which is the capital of Bayelsa State, Nigeria. Yenagoa lies between latitudes $4^{\circ} 55^{\prime}$ and $5^{\circ} 02^{\prime}$ north of the Equator and longitudes $6^{\circ} 15^{\prime}$ and $6^{\circ} 25^{\prime}$ east of the Greenwich meridian. It is the most economically viable town in the state and occupies an area of about $706 \mathrm{~km}^{2}$ [16]. The mean daily temperature range is $25^{\circ} \mathrm{C}$ to $31^{\circ} \mathrm{C}$ and average annual rainfall of about $3000 \mathrm{~mm}$. The current administrative status of Yenagoa has attracted people from different walks of life, which have increased the population of the city and the subsequent increase in waste (liquid \& solid) generation, through several economic activities, such as car wash bays, domestic, commercial, and industrial production. Unfortunately, both liquid and solid waste disposal is still a great challenge in the city as wastes are most time not treated and improperly disposal, which had led to surface water pollution in the city. Unfortunately, some households still depend on surface water for their domestic supply in the city. Since the cost of the conventional methods of wastewater treatment is beyond the reach of many of the waste generators, such as the car wash operators, there is therefore a compelling need to adopt other more cost effective, eco-friendly, and efficient methods of remediation of polluted surface water.

\section{B. Method of Wastewater Sample Collection and Locations}

The cluster or area sampling design was used during plants sampling. Wastewater samples were collected three times monthly in both morning and evening shift at the specified geographic locations as presented in Table I.

The wastewater samples from six car wash locations were collected thrice monthly for six consecutive months from April to September 2020. Meanwhile the samples were collected in the morning (8-12noon) and evening (4-7p.m.) hours of the specified days in each month. The different car wash locations where the wastewater samples were collected include Vera car wash bay, Glory land car wash bay, Gladies car wash bay, Afam car wash bay, Bolex car wash and Edom car wash. The selection of these locations was purposively done on the basis that they were located along aquatic ecosystems in Yenagoa and into which wastewaters from the aforementioned car wash bays are drained. One litre plastic bottle was used to collect the samples from the locations. The bottles were washed with tap water to keep the bottles free from any form of contamination. The bottles were cleaned with nitric acid, washed with distilled water twice, again rinsed with the wastewater sample to be collected and filled up with the wastewater samples allowing only a small space at the neck of the bottle as adopted by [10]. In order to assess the biological oxygen demand $\left(\mathrm{BOD}_{5}\right)$, wastewater samples were collected in $250 \mathrm{~cm}^{3}$ bottle with stoppers, and one millimeter each of Winkler's solutions A and B was added to each of the samples on site to fix the oxygen as adopted by [17].The wastewater samples were stored in ice box and subsequently transported to the laboratory for analysis.

TABLE I: COORDINATES OF WASTEWATER SAMPLE LOCATIONS IN YENAGOA METROPOLIS

\begin{tabular}{ccc}
\multicolumn{3}{c}{ YENAGOA METROPOLIS } \\
\hline Sample Locations & Latitude & Longitude \\
\hline Vera car wash bay & $5^{0} 01^{1} 19^{11} \mathrm{~N}$ & $6^{0} 23^{1} 4^{11} \mathrm{E}$ \\
Gloryland car wash bay & $4^{0} 56^{1} 53^{11} \mathrm{~N}$ & $6^{0} 20^{1} 55^{11} \mathrm{E}$ \\
Gladies car wash bay & $4^{0} 50^{1} 5^{11} \mathrm{~N}$ & $6^{0} 21^{1} 9^{11} \mathrm{E}$ \\
Afam car wash & $5^{0} 00^{1} 17^{11} \mathrm{~N}$ & $6^{0} 22^{1} 28^{11} \mathrm{E}$ \\
Bolex car wash & $4^{0} 57^{1} 49^{11} \mathrm{~N}$ & $6^{0} 23^{1} 55^{11} \mathrm{E}$ \\
Edom car wash & $4^{0} 58^{1} 16^{11} \mathrm{~N}$ & $6^{0} 21^{1} 7^{11} \mathrm{E}$ \\
\hline
\end{tabular}

Source: Authors' fieldwork. 


\section{Plants Samples Collection}

Plants samples were collected from different aquatic ecosystems in Yenagoa metropolis. The plants samples were collected based on the principle of species richness estimate using quadrant sampling method. The collected plants include Nymphaea Nouchalli (water lily), Lemna Minor (duckweed), Pistia Stratiotes (water lettuce), Ceratophyllum Demersum (hornwort) and Eichhornia Crassipes (water hyacinth) and were rinsed with distilled water to remove all the dirt. Thereafter, 2 weeks acclimatization period was set to stabilize the plants.

\section{Experimental Procedure}

The experiment was conducted in a greenhouse (constructed by the researchers) with five circular plastic bowls containing 15 litres of composite wastewater samples from the sampled locations for the study and were set at ambient temperature range of $25-30^{\circ} \mathrm{C}$. Thereafter, each of the plant samples of similar weight was introduced into the respective bowls with fifteen (15) litres of wastewater samples. The wastewater samples directly collected from the sample locations were used and it was put together to form a composite or representative wastewater. The experimental period lasted for six (6) weeks, whereas a circular plastic bowl with fifteen (15) litres of the raw wastewater sample without plant specimen served as control.

Throughout the period of the experiment the water loss from the bowls through evapo-transpiration in both the experimental and the control system during the experiment was compensated by adding distilled water into them as it was adopted by [18]. The changes in the physico-chemical characteristics in the treated wastewater samples were determined after the specific stipulated days of the experiment by collecting the treated effluent from each bowl for analysis. At the end of the six weeks retention period, the concentrations of the selected parameters were determined using standard method as suggested by [17].

\section{E. Laboratory Analysis of Physico-Chemical Characteristics of Wastewater}

The analysed physico-chemical parameters in the wastewater samples include $\mathrm{pH}$, turbidity, biological oxygen demand (BOD), chemical oxygen demand (COD), dissolved oxygen (DO), nitrate $\left(\mathrm{NO}_{3}\right)$ and phosphate $\left(\mathrm{PO}_{4}\right)$. These parameters were analyzed using standard methods as prescribed in the manual of APHA 1995 as cited in [19].

\section{F. Statistical Analysis}

Data obtained for the study were analyzed using descriptive statistics (tables \& percentages). The descriptive statistics were employed to determine and present the concentrations of studied physico-chemical characteristics of wastewater by the sampled plants at specified intervals of 14 , 28 and 42 days of treatment. The measured concentrations of the physico-chemical parameters were compared among the three specified time intervals to determine the time period with the highest uptake by the respective sampled plants.

\section{RESUlTS AND DisCUSSION}

Five plants were selected to determine their potency in the remediation of wastewater effluents from car wash bays in Yenagoa metropolis. The plants include Nymphaea Nouchalli (water lily), Lemna Minor (duckweed), Pistia Stratiotes (water lettuce), Ceratophyllum Demersum (hornwort) and Eichhornia Crassipes (water hyacinth). These plants were used to determine the uptake of the physico-chemical concentration of seven selected parameters which include $\mathrm{pH}$, turbidity, biological oxygen demand $\left(\mathrm{BOD}_{5}\right)$, chemical oxygen demand (COD), dissolved oxygen (DO), nitrate $\left(\mathrm{NO}_{3}\right)$ and phosphate $\left(\mathrm{PO}_{4}\right)$. The mean, range, and control values of the concentration of the selected physico-chemical parameters of the sampled wastewater after the specified 14, 28-, and 42-days treatment periods are presented in Table II.

\section{A. Mean Concentration of Turbidity at Different Treatment Intervals}

The mean concentration of turbidity for the three treatment periods (14, $28 \& 42$ days) are presented in Table II. The control value for turbidity was 262 NTU, However, after treatment with Lemna Minor, the turbidity concentration reduced significantly to $71 \mathrm{NTU}(72.9 \%)$ after 14 days of treatment; 22 NTU (91.6\%) after 28 days and 10.03 NTU (96.2\%) on day 42. This shows that Lemna Minor was able to uptake a total of 251.97 NTU of the original concentration. However, 191 NTU of the 262 NTU value was absolved in the first 14 days of treatment. Comparatively, the uptake efficiency of Nymphaea Nouchalli, was quite higher than that of Lemna Minor, as the turbidity concentration in the wastewater was reduced from 262 NTU to 15 NTU (94.3\%) on day 14 of the treatment; while on day 42 at the completion of the treatment, the concentration had reduced to barely 5.07 NTU, which falls within the World Health Organization (WHO) 5 NTU threshold for turbidity concentration in drinking water supply.

Meanwhile, $P$. Stratiotes (water lettuce) reduced turbidity level from 262 NTU to 11.67 NTU with a total uptake of 250.33 NTU (95.5\%) in 14 days of treatment while the concentration reduced further to $7.33 \mathrm{NTU}$ with an uptake of 254.67 NTU (97.2\%) in 28 days. On day 42, the concentration has reduced to 1.03 NTU (99.6\%). This shows that $P$. Stratiotes has the capability to remediate the turbidity of polluted water to its original state after 42 days of treatment. Although, E. Crassipes was able to reduce turbidity concentration in the wastewater to $18.67 \mathrm{NTU}$ $(92.9 \%)$ from the initial level of 262 NTU in 14 days, however, this level was less than what was achieved by $P$. Stratiotes, within the same period. At the end of the treatment period (42 days), turbidity value has been reduced to 14.67 NTU (94.4\%), which represents an uptake of 247.54 NTU, which was still higher than the WHO threshold of 5 NTU for drinking water. Finally, the efficiency level of uptake of turbidity from wastewater by $C$. Demersum was higher than that of E. Crassipes, as the turbidity value was reduced to 14.33, 10.07 and 2.07 NTU for 14, 28 and 42 days, respectively. This means that at the end of the treatment period (42 days) C. Demersum had been able to absolved 259.93 NTU $(99.2 \%)$ of the 262 concentration before the treatment, which makes the turbidity value at the end of 42 
days to fall within the WHO threshold for drinking water supply.

The study has revealed that the bio-removal efficiency of turbidity by the cultured plants takes the order of $P$. Stratiotes $>$ C. Demersum > N. Nouchalli> L. Minor > E. Crassipes. However, the turbidity removal rate of $P$. Stratiotes recorded in this study was higher than the turbidity values of about $60 \%$ that was recorded by [20] in their study of the treatment plots of two storm water detention pond using P. Stratiotes. It was evident that the average turbidity removal level of $L$. Minor in this study was higher than the findings of [21] but lower than the findings reported by [22].

TABLE II: PHYSICO-CHEMICAL PARAMETERS IN WASTEWATER AFTER 14, 28 AND 42 DAYS OF TREATMENT

\begin{tabular}{|c|c|c|c|c|c|c|c|c|}
\hline $\begin{array}{c}\text { Sampled } \\
\text { Plant }\end{array}$ & REP & $\begin{array}{c}\text { Turbidity } \\
\text { (NTU) }\end{array}$ & $\mathrm{PH}$ & $\begin{array}{c}\mathrm{NO}_{3} \\
(\mathrm{mg} / \mathrm{l})\end{array}$ & $\mathrm{PO}_{4}(\mathrm{mg} / \mathrm{l})$ & DO (mg/l) & $\begin{array}{l}\text { BOD } \\
(\mathrm{mg} / \mathrm{l})\end{array}$ & $\begin{array}{l}\mathrm{COD} \\
(\mathrm{mg} / \mathrm{l})\end{array}$ \\
\hline \multirow{7}{*}{$\begin{array}{l}\text { Lemna } \\
\text { Minor }\end{array}$} & Control & 262.00 & 4.20 & 99.00 & 8.61 & 5.69 & 3.24 & 9.76 \\
\hline & 14 days mean & $71.00 \pm 1.00$ & $2.58 \pm 0.01$ & $6.33 \pm 0.01$ & $7.50 \pm 0.01$ & $6.78 \pm 0.02$ & $1.63 \pm 0.00$ & $3.29 \pm 0.01$ \\
\hline & Range & $70.00-72.00$ & $2.55-2.59$ & $6.30-6.35$ & $7.49-7.52$ & $6.78-6.79$ & $1.59-1.65$ & $3.28-3.36$ \\
\hline & 28 days mean & $22.00 \pm 1.00$ & $2.51 \pm 0.01$ & $0.11 \pm 0.01$ & $7.31 \pm 0.01$ & $7.15 \pm 0.01$ & $1.25 \pm 0.01$ & $2.73 \pm 0.02$ \\
\hline & Range & $21.00-23.00$ & $2.50-2.51$ & $0.10-0.11$ & $7.29-7.32$ & $7.12-7.20$ & $1.24-1.25$ & $2.71-2.75$ \\
\hline & 42 days mean & $10.03 \pm 0.06$ & $2.54 \pm 0.02$ & $0.03 \pm 0.00$ & $4.20 \pm 0.10$ & $7.26 \pm 0.02$ & $1.15 \pm 0.02$ & $2.50 \pm 0.01$ \\
\hline & Range & $10.00-10.06$ & $2.53-2.56$ & $0.00-0.05$ & $4.10-4.30$ & $7.22-7.28$ & $1.13-1.17$ & $2.11-3.23$ \\
\hline \multirow{6}{*}{$\begin{array}{c}N . \\
\text { Nouchalli }\end{array}$} & 14 days mean & $15.00 \pm 1.00$ & $2.80 \pm 0.01$ & $5.20 \pm 0.01$ & $3.40 \pm 0.01$ & $5.95 \pm 0.45$ & $2.16 \pm 0.02$ & $4.69 \pm 0.01$ \\
\hline & Range & $14.00-16.00$ & $2.77-2.81$ & $5.19-5.21$ & $3.39-3.41$ & $5.89-6.01$ & $1.15-2.18$ & $4.68-4.70$ \\
\hline & 28 days mean & $10.33 \pm 0.58$ & $2.78 \pm 0.01$ & $0.43 \pm 0.58$ & $1.00 \pm 0.05$ & $6.27 \pm 0.01$ & $2.05 \pm 0.02$ & $4.10 \pm 0.01$ \\
\hline & Range & $10.00-11.00$ & $2.76-2.81$ & $0.39-0.45$ & $0.99-1.10$ & $6.25-6.29$ & $2.03-2.07$ & $4.05-4.11$ \\
\hline & 42 days mean & $5.07 \pm 0.05$ & $2.50 \pm 0.02$ & $0.03 \pm 0.00$ & $1.00 \pm 0.05$ & $7.10 \pm 0.01$ & $2.01 \pm 0.01$ & $4.05 \pm 0.02$ \\
\hline & Range & $5.00-5.10$ & $2.48-2.52$ & $0.00-0.04$ & $1.00-1.01$ & 7.09-7.11 & $2.00-2.02$ & $4.04-4.07$ \\
\hline \multirow{6}{*}{ P. Stratiotes } & 14 days mean & $11.67 \pm 0.58$ & $2.80 \pm 0.01$ & $4.50 \pm 0.01$ & $2.55 \pm 0.02$ & $7.36 \pm 0.01$ & $1.75 \pm 0.01$ & $4.64 \pm 0.01$ \\
\hline & Range & $11.00-12.00$ & $2.79-2.81$ & $4.49-4.51$ & $2.52-2.56$ & $7.35-6.37$ & $1.741-1.76$ & $4.63-4.65$ \\
\hline & 28 days mean & $7.33 \pm 0.57$ & $2.50 \pm 0.01$ & $2.20 \pm 0.01$ & $0.95 \pm 0.01$ & $6.42 \pm 0.02$ & $1.08 \pm 0.01$ & $3.62 \pm 0.03$ \\
\hline & Range & $7.00-8.00$ & $2.50-2.51$ & $2.10-2.21$ & $0.94-0.96$ & $6.39-6.44$ & $1.07-1.09$ & $3.57-3.65$ \\
\hline & 42 days mean & $1.03 \pm 0.05$ & $2.49 \pm 0.01$ & $0.10 \pm 0.00$ & $0.06 \pm 0.03$ & $6.76 \pm 0.01$ & $1.02 \pm 0.02$ & $3.42 \pm 0.02$ \\
\hline & Range & $1.02-1.04$ & $2.37-2.59$ & $0.10-0.11$ & $0.00-0.10$ & $6.75-6.77$ & $1.00-1.03$ & $3.40-3.43$ \\
\hline \multirow{6}{*}{ E. Crassipes } & 14 days mean & $18.67 \pm 0.58$ & $3.40 \pm 0.01$ & $1.01 \pm 0.06$ & $5.51 \pm 0.06$ & $6.03 \pm 0.57$ & $1.95 \pm 0.01$ & $4.56 \pm 0.02$ \\
\hline & Range & $18.00-19.00$ & $3.39-3.41$ & $1.00-1.01$ & $5.51-5.52$ & $6.02-6.03$ & $1.94-1.96$ & $4.54-4.58$ \\
\hline & 28 days mean & $15.00 \pm 1.00$ & $2.90 \pm 0.01$ & $0.11 \pm 0.01$ & $4.41 \pm 0.07$ & $6.34 \pm 0.01$ & $1.32 \pm 0.02$ & $3.43 \pm 0.02$ \\
\hline & Range & $14.00-16.00$ & $2.90-2.91$ & $0.10-0.11$ & $4.40-4.41$ & $6.32-6.35$ & $1.30-1.33$ & $3.39-3.45$ \\
\hline & 42 days mean & $14.67 \pm 0.54$ & $2.20 \pm 0.01$ & $0.01 \pm 0.02$ & $3.51 \pm 0.06$ & $6.63 \pm 0.57$ & $1.15 \pm 0.01$ & $2.56 \pm 0.02$ \\
\hline & Range & $14.60-14.71$ & $2.19-2.21$ & $0.00-0.01$ & $3.50-3.52$ & $6.60-6.64$ & $1.14-1.16$ & $2.54-2.58$ \\
\hline \multirow{6}{*}{$\begin{array}{c}\text { C.Demersu } \\
m\end{array}$} & 14 days mean & $14.33 \pm 2.31$ & $2.61 \pm 0.02$ & $4.70 \pm 0.01$ & $4.01 \pm 0.01$ & $5.77 \pm 0.01$ & $1.75 \pm 0.04$ & $4.93 \pm 0.01$ \\
\hline & Range & $12.00-18.00$ & $2.60-2.63$ & $4.69-4.72$ & $4.00-4.02$ & 5.74- 5.78 & $1.74-1.76$ & $4.92-4.94$ \\
\hline & 28 days mean & $10.07 \pm 1.53$ & $2.50 \pm 0.01$ & $3.71 \pm 0.01$ & $3.50 \pm 0.02$ & $5.99 \pm 0.01$ & $1.44 \pm 0.02$ & $4.54 \pm 0.02$ \\
\hline & Range & $9.36-10.86$ & $2.50-2.51$ & $3.71-3.72$ & $3.48-3.52$ & $5.98-6.01$ & $1.44-1.45$ & $4.53-4.55$ \\
\hline & 42 days mean & $2.07 \pm 0.08$ & $2.40 \pm 0.02$ & $3.73 \pm 0.17$ & $1.60 \pm 0.02$ & $6.25 \pm 0.01$ & $1.20 \pm 0.01$ & $4.20 \pm 1.14$ \\
\hline & Range & $2.00-2.10$ & $2.38-2.42$ & $3.70-3.75$ & $1.58-1.62$ & $6.22-6.26$ & $1.13-1.21$ & $4.17-4.22$ \\
\hline $\begin{array}{c}\text { WHO } \\
\text { Permissible } \\
\text { Limits } \\
\end{array}$ & & 5.00 & $6.5-8.5$ & 50 & 5.00 & 5.00 & 50.0 & 250 \\
\hline
\end{tabular}

Source: Authors' fieldwork, 2020.

\section{B. Mean Concentration of $\mathrm{pH}$ at Different Treatment Intervals}

Table II also shows the mean concentration of $\mathrm{pH}$ at different treatment intervals. The results revealed that $L$. Minor increased the acidity level of the initial $\mathrm{pH}$ concentration from 4.20 (control value) to 2.58 with a total uptake of $1.62(38.6 \%)$ after 14 days of treatment. However, the acidity level increased further to 2.51 (40.2\%) and reduced to $2.54(39.5 \%)$ in 28 and 42 days retention periods, respectively. However, the reduced acidity level indicated in the L. Minor treated wastewater in 42 days was negligible. The results also indicated that there was an increased acidity level in N. Nouchalli treated wastewater samples from 4.20 to 2.80 with an uptake of $1.40(33.3 \%)$ in 14 days. The acidity of the wastewater increased further to $2.78(33.8 \%)$ and 2.50 $(40.5 \%)$ after 28 and 42 days of treatment, respectively. Similar trend was observed in P. Stratiotes treated wastewater samples, as there was increased acidity of $\mathrm{pH}$ concentration from 4.20 to $2.80(33.3 \%), 2.50(40.5 \%)$ and $2.49(40.7 \%)$ after 14, 28 and 42 days of treatment, respectively. Furthermore, the study recorded increase acidity in $\mathrm{pH}$ concentrations in both E. Crassipes and C. Demersum treated wastewater samples, as the acidity increased progressively from $3.40(19 \%)$ to $2.20(47.6 \%)$, and $2.61(37.9 \%)$ to 2.40 (42.9\%), respectively from 14 to 42 days. The overall analysis indicated that all the plants used for the experiment were found to increase the acidity of $\mathrm{pH}$ concentration in the treated wastewater samples, as all the values were below the WHO thresholds of 6.5-8.5 for potable water supply.

However, the increased acidity level of $\mathrm{pH}$ recorded in the L. Minor treated wastewater sample in this study was higher than the findings reported by [23]. Meanwhile, the percentage reduction values of $\mathrm{pH}$ concentration in $P$. Stratiotes and $E$. Crassipes treated wastewater samples were lower than the $\mathrm{pH}$ reduction level of 50-75\% achieved in the study carried out by [24], but higher than the slight reduction level of $\mathrm{pH}$ achieved by [25] in their study of the phytoremediation of landfill leachate waste contaminants using $P$. Stratiotes and $E$. Crassipes. The $\mathrm{pH}$ reduction observed in the $P$. Stratiotes treated wastewater sample correlate with the findings of [26] that $P$. Stratiotes reduced alkaline $\mathrm{pH}$ concentration to neutral. More so, the level of $\mathrm{pH}$ reduction observed in the $E$. Crassipes treated wastewater sample in this study was also higher than the value recorded by [27]. But it confirmed the study by [28] that there was a reduction in the $\mathrm{pH}$ values after the 6 weeks treatment periods, which revealed that all treatments tend toward being acidic. It is pertinent to note 
that, the increased acidity level of the $\mathrm{pH}$ concentration in all the treated wastewater samples by the plants confirmed the findings reported by [26] that the $\mathrm{pH}$ reduction may be attributable to the uptake of nutrients and salt by the aquatic macrophytes and fallback of some death leaves before the time of harvest.

\section{Mean Concentration of Nitrate $\left(\mathrm{NO}_{3}\right)$ at Different Treatment Intervals}

The $\mathrm{NO}_{3}$ concentration in the control wastewater sample was $99 \mathrm{mg} / \mathrm{l}$. This value was reduced drastically to $0.03 \mathrm{mg} / \mathrm{l}$, with a total uptake of $98.97 \mathrm{mg} / \mathrm{l}(99.96 \%)$ after 42 days of treatment with $L$. Minor. The same value of $0.03 \mathrm{mg} / \mathrm{l}$ was also recorded after 42 days of treatment with $N$. Nouchalli. However, on day 14 of the treatment, the recorded values for L. Minor and N. Nouchalli, were $6.33 \mathrm{mg} / \mathrm{l}$ and $5.20 \mathrm{mg} / \mathrm{l}$, respectively. This shows that $N$. Nouchalli has higher capacity to absolve nitrate than L. Minor on the first two weeks of treatment.

On the other hand, the recorded nitrate values of the treated wastewater with $P$. Stratiotes, E. Crassipes and C. Demersum were $4.50 \mathrm{mg} / \mathrm{l}, 1.01 \mathrm{mg} / \mathrm{l}$ and $4.70 \mathrm{mg} / \mathrm{l}$, respectively after 14 days of treatment. While the values were $0.10 \mathrm{mg} / 1,0.01 \mathrm{mg} / \mathrm{l}$ and $3.73 \mathrm{mg} / \mathrm{l}$, respectively after 42 days of treatment. The overall result indicated that all the plants used for the experiment were good bioremediators of nitrate. It was evident that the bioremoval efficiency of nitrate by the plants under review take the order of E. Crassipes $>N$. Nymphaea > L. Minor > P. Stratiotes >C. Demersum. However, the nitrate removal level of $L$. Minor recorded in this study was higher than the findings reported by [23] but was lower than what was reported by [29]. Meanwhile, the percentage value of nitrate removal potential by L. Minor recorded in this study was in consonant with the findings reported by [22]. The nitrate reduction level of $P$. Stratiotes observed in this study was higher than the percentage values reported by [30], [25]. More so, nitrate bioremoval efficiency of E. Crassipes observed in this study was higher than the findings reported by [31], [25]. The nitrate removal efficiency of $C$. Demersum was in consonant with the findings of [32].

\section{Mean Concentration of Phosphate $\left(\mathrm{PO}_{4}\right)$ at Different Treatment Intervals}

The mean concentration of $\mathrm{PO}_{4}$ on day 14 after treatment with Lemna Minor was $7.50 \mathrm{mg} / \mathrm{l}$, with a control value of 8.61 $\mathrm{mg} / \mathrm{l}$. This translates to an uptake of $1.11 \mathrm{mg} / \mathrm{l}(12.9 \%)$. The concentration of $\mathrm{PO}_{4}$ reduced further to $7.31 \mathrm{mg} / 1$ (15.1\%) and $4.20 \mathrm{mg} / \mathrm{l}(51.2 \%)$ on day 28 and 42 , respectively. This shows that the amount of uptake by the plant was highest on the last 14 days of the treatment where an uptake value of $3.11 \mathrm{mg} / \mathrm{l}$ was recorded from the value on day 28 . This implies that to achieve utmost absorption of $\mathrm{PO}_{4}$ from wastewater treated with Lemna Minor, the treatment should extent to 42 days. This is an indication that short retention period was inadequate for Lemna Minor to absorb considerable amount of nutrient from wastewater. In contrast to Lemna Minor, Nymphaea Nouchalli reduced the concentration of $\mathrm{PO}_{4}$ to $3.40 \mathrm{mg} / \mathrm{l}(60.5 \%)$ from $8.61 \mathrm{mg} / \mathrm{l}$, which translates to an uptake of $5.21 \mathrm{mg} / \mathrm{l}$ on day 14 of the treatment. On day 28 , the $\mathrm{PO}_{4}$ value has further reduced to $1.0 \mathrm{mg} / \mathrm{l}$, which translates to an uptake of $7.61 \mathrm{mg} / \mathrm{l}(88.4 \%)$; while the value on day 42 remain unchanged at $1.0 \mathrm{mg} / \mathrm{l}$. This means that Nymphaea
Nouchalli reached the maximum capacity of absorption of nutrient on day 28 . The test also shows that $P$. Stratiotes was very efficient in the absorption of $\mathrm{PO}_{4}$ from wastewater as the values decreased progressively from $8.61 \mathrm{mg} / \mathrm{l}$ (control) to $2.55(70.4 \%), 0.95(89.0 \%)$ and $0.06 \mathrm{mg} / \mathrm{l}(99.3 \%)$ for 14,28 and 42 days of treatment, respectively. Unlike the case of Nymphaea Nouchalli, P. Stratiotes continued to absorb nutrient at day 42 , with the nutrient almost completely removed from the wastewater.

Although the test also revealed that E. Crassipes equally reduced the concentration of $\mathrm{PO}_{4}$ progressively, however, the efficiency level was far less than other plants. For example, the $\mathrm{PO}_{4}$ concentration was $5.51(36 \%), 4.41(48.8 \%)$ and $3.51 \mathrm{mg} / 1(59.2 \%)$ after treatment for 14,28 and 42 days, respectively. Similar to other plants, $C$. Demersum equally reduced the concentration of $\mathrm{PO}_{4}$ progressively from 8.61 (control) to $4.01,3.50$ and $1.60 \mathrm{mg} / \mathrm{l}$ for 14,28 and 42 days, respectively. In the final analysis, it was observed that all the plants were able to reduce the concentration of $\mathrm{PO}_{4}$ to less than $5 \mathrm{mg} / \mathrm{l} \mathrm{WHO}$ permissible threshold on day 42. This means that all the cultured plants are good bioremediators of phosphate and their efficiency level takes the order of $P$. Stratiotes $>$ N. Nymphaea $>$ C. Demersum $>$ L. Minor $>$ E. Crassipes.

The phosphate removal potentials by L. Minor observed in this study was lower than the findings by [21] but confirmed the report by [33] that it can be used effectively for contaminants removal and bioremediation for phosphate and other nutrients from wastewater and can absorb a considerable amount of nutrient in short retention period. It was also indicated that the phosphate removal rate by $P$. Stratiotes was higher than the findings of [30], [25]. The findings also revealed that the phosphate removal potentials by E. Crassipes were lower than the findings of [31], [25].

\section{E. Mean Concentration of Dissolved Oxygen (DO) at Different Treatment Intervals}

The mean concentration of DO as presented in Table II indicated that after treatment with L. Minor, the DO concentration increased to $6.78 \mathrm{mg} / 1$ (19.2\%) from the control value of $5.69 \mathrm{mg} / \mathrm{l}$ after 14 days. The DO concentration increased further to $7.15 \mathrm{mg} / \mathrm{l}(25.7 \%)$ and $7.26 \mathrm{mg} / \mathrm{l}(27.6 \%)$ at 28 and 42 days treatment intervals, respectively. However, it was observed that the increased value of DO in the L. Minor treated wastewater sample was marginal at prolonged retention time. Also, an increase in DO was observed in $N$. Nymphaea treated wastewater. The values increased to 5.95 (4.6\%), $6.27(10.2 \%)$ and $7.10 \mathrm{mg} / 1$ (24.8\%) after treatment for 14, 28 and 42 days, respectively from the control value of $5.69 \mathrm{mg} / \mathrm{l}$. Similar trends were also recorded in the $P$. Stratiotes, E. Crassipes and C. Demersum treated wastewater samples with DO concentration increasing to $7.36 \mathrm{mg} / \mathrm{l}$ (29.3\%), $6.42 \mathrm{mg} / \mathrm{l}(12.8 \%)$ and $6.76 \mathrm{mg} / \mathrm{l}(18.8 \%)$ for $P$. Stratiotes; $6.03 \mathrm{mg} / \mathrm{l}(6.0 \%), 6.34 \mathrm{mg} / \mathrm{l}(11.4 \%)$ and $6.63 \mathrm{mg} / \mathrm{l}$ (16.5\%) for E. Crassipes; and was $5.77 \mathrm{mg} / \mathrm{l}$ (1.4\%), 5.99 $\mathrm{mg} / \mathrm{l}(5.3 \%)$ and $6.25 \mathrm{mg} / \mathrm{l}(9.8 \%)$ for $C$. Demersum after 14 , 28 and 42 days, respectively. The overall results showed that, there was an increase in DO concentration in all the treated wastewater samples. Meanwhile, the DO improved efficiency by the plants under review takes the order of $L$.Minor $>N$. Nymphaea $>$ E. Crassipes $>$ P. Stratiotes $>C$. Demersum. 
It should be noted however, that the DO increased level in the $P$. Stratiotes treated wastewater sample observed in this study was far lower than the percentage value of $59.6 \%$ achieved by [30]. Meanwhile the measured DO in the $L$. Minor treated wastewater sample was lower than the findings reported by [34] in their study of the use of duckweed in the treatment of wastewater from washing of Sisal fiber. The increased percentage values of DO concentration in $C$. Demersum treated wastewater sample confirmed the findings of [32]. More so, the increase in the level of DO in the $E$. Crassipes treated wastewater sample was lower than the percentage values achieved by [30].

\section{F. Mean Concentration of Biological Oxygen Demand $\left(\mathrm{BOD}_{5}\right)$ at Different Treatment Intervals}

As shown in Table II, the control value of $\mathrm{BOD}_{5}$ was $3.24 \mathrm{mg} / \mathrm{l}$. However, after treatment with L. Minor, the concentration reduced to mean values of $1.63 \mathrm{mg} / \mathrm{l}(49.7 \%)$, $1.25 \mathrm{mg} / \mathrm{l}(61.4 \%)$ and $1.15 \mathrm{mg} / \mathrm{l}(64.5 \%)$ on day 14,28 and 42 , respectively. The result also showed that N. Nouchalli decreased BOD concentration from the initial concentration of $3.24 \mathrm{mg} / \mathrm{l}$ to $2.16 \mathrm{mg} / \mathrm{l}$ with a total uptake of $1.08 \mathrm{mg} / \mathrm{l}$ (33.3\%), 2.05mg/l (36.7\%) and 2.01mg/l (38.0\%) after 14, 28 and 42 days of treatment, respectively. This trend was also observed in the wastewater sample treated by $P$. Stratiotes and $C$. Demersum. The results showed that there were progressive reductions of $\mathrm{BOD}_{5}$ concentration as the retention time increases. The mean recorded values for $P$. Stratiotes were $1.75 \mathrm{mg} / \mathrm{l}(46.0 \%), 1.08 \mathrm{mg} / \mathrm{l}(66.7 \%)$ and $1.02 \mathrm{mg} / \mathrm{l}(68.5 \%)$; while that of $C$. Demersum were $1.75 \mathrm{mg} / \mathrm{l}(46.0 \%), 1.44 \mathrm{mg} / \mathrm{l}(55.6 \%)$ and $1.20 \mathrm{mg} / \mathrm{l}(63.0 \%)$ after 14, 28 and 42 days of treatment, respectively. Although both plants have equal rate of uptake of $\mathrm{BOD}_{5}(1.49 \mathrm{mg} / \mathrm{l})$ on day 14 , however, their absorption rate differ on day 28 and 42 , as $P$. Stratiotes proved to be more efficient at these treatment intervals. Similarly, E. Crassipes progressively reduced $\mathrm{BOD}_{5}$ concentration as the treatment period increases. It reduced the control value of $3.24 \mathrm{mg} / \mathrm{l}$ to mean values of $1.95 \mathrm{mg} / \mathrm{l}(39.8 \%), 1.32 \mathrm{mg} / \mathrm{l}(59.3 \%)$ and $1.15 \mathrm{mg} / \mathrm{l}$ $(64.5 \%)$ for day 14,28 and 42, respectively.

In all, the $\mathrm{BOD}_{5}$ bioremediation efficiency of the investigated plants takes the order of $P$. Stratiotes $>L$. Minor $>$ E. Crassipes, > C. Demersum > Nymphaea, respectively. However, the $\mathrm{BOD}_{5}$ removal efficiency of L. Minor was lower than the findings of [22], [34]. Meanwhile, the $\mathrm{BOD}_{5}$ bioremediation efficiency by $E$. Crassipes was higher than the values achieved by [27] but was lower than the findings reported by [24]. The percentage values of $\mathrm{BOD}_{5}$ removal potential by $E$. Crassipes was lower than the $\mathrm{BOD}_{5}$ reduction value of $93 \%$ achieved by [26] but contradicts the findings of [30] that reported an increase in $\mathrm{BOD}_{5}$ concentration after treatment.

\section{G. Mean Concentration of Chemical Oxygen Demand (COD) at Different Treatment Intervals}

The mean concentration of COD as presented in Table II revealed that $L$. Minor decreased COD concentration from $9.76 \mathrm{mg} / \mathrm{l}$ to $3.29 \mathrm{mg} / \mathrm{l}$ with a total uptake of $6.47 \mathrm{mg} / 1(66.3 \%)$ in 14 days. The concentration reduced further to $2.73 \mathrm{mg} / \mathrm{l}$ $(72.0 \%)$ and $2.50 \mathrm{mg} / \mathrm{l}(74.4 \%)$ in 28 and 42 days of treatment, respectively. Similar trend was observed in $N$. Nouchalli, P. Stratiotes, E. Crassipes and C. Demersum treated wastewater samples with COD reduced to mean values of $4.69 \mathrm{mg} / \mathrm{l}(51.9 \%), 4.10 \mathrm{mg} / \mathrm{l}(58.0 \%)$ and $4.05 \mathrm{mg} / \mathrm{l}$ $(58.5 \%)$ for $N$. Nouchalli; $4.64 \mathrm{mg} / \mathrm{l}(52.5 \%), 3.62 \mathrm{mg} / \mathrm{l}$ $(62.9 \%)$ and $3.42 \mathrm{mg} / \mathrm{l}(65.0 \%)$ for P. Stratiotes; $4.56 \mathrm{mg} / \mathrm{l}$ (53.3\%), $3.43 \mathrm{mg} / \mathrm{l}(64.9 \%)$ and $2.56 \mathrm{mg} / \mathrm{l}(73.8 \%)$ for $E$. Crassipes and $4.93 \mathrm{mg} / \mathrm{l}(49.5 \%), 4.54 \mathrm{mg} / \mathrm{l}(53.5 \%)$ and 4.20 $\mathrm{mg} / \mathrm{l}(57.0 \%)$ for $C$. Demersum from the control value of 9.76 $\mathrm{mg} / \mathrm{l}$ after treatment for 14,28 and 42 days, respectively. Meanwhile, the COD bioremediation efficiency of the cultured native plants takes the order of L. Minor $>E$. Crassipes > P. Stratiotes > N. Nouchalli.> C. Demersum.

However, the COD removal efficiency by L. Minor was lower than the result achieved by [34]. It was also observed that the COD reduction by E. Crassipes was higher than the findings of [35], but lower than the findings reported by [36], [25]. Meanwhile, the COD reduction values by E. Crassipes were in consonant with the percentage range reported by [24]. The COD bioremoval potential by $P$. Stratiotes was lower than the findings reported by [25], but higher than the findings of.[30]. Meanwhile, the COD reduction values are in consonant with the percentage range of $50-75 \%$ reported by [24].

\section{CONCLUSION}

The study has revealed that the selected five native aquatic plants were able to reduce significantly the concentrations of the identified physico-chemical parameters in the wastewater effluents from car wash bays in Yenagoa metropolis. All the plants were able to remediate the initial concentrations of the selected parameters, which were obviously above the WHO thresholds for potable water to levels that are within the permissible limits at the end of the experiment, except $\mathrm{pH}$ that increased in acidity. It was also observed that the potency of the selected plants varies across the parameters and time intervals. Furthermore, in almost all the cases, the rate of uptake of the parameters was highest in the first 14 days of treatment, because the plants were fresh and had higher capacity to absorb the parameters. It was found that $P$. Stratiotes was the best absorber of turbidity, $\mathrm{PO}_{4}$ and $\mathrm{BOD}_{5}$; while E. Crassipes was the best plant for removal of $\mathrm{NO}_{3}$, and L. Minor the most efficient for the removal of COD and increase of DO in wastewater. It can therefore be concluded that all the plants are good phytoremediators. Since the potentials of each of the plants varies depending on the physico-chemical parameter in question, it is therefore recommended that the choice of plant to use for any remediation work should be determined based on their efficiency level for a given parameter. However, more study should be done on the phytoremediation efficiencies of these plants on other parameters that were not included in this work.

\section{ACKNOWLEDGEMENTS}

The authors wish to thank Dr. P.A. Bariweni for his comments and suggestions on the draft manuscript. We also express our profound gratitude to the management of Kemnolli Nigeria Limited, where the laboratory analysis took place for their cooperation. 


\section{REFERENCES}

[1] Werimo K, Bergwerff AA, Seinen W. Residue levels of organochlorines and organophosphates in water, fish and sediments from lake Victoria-Kenyan portion. Aquati. Ecosyst. Health Manage. 2009; 12: 337-341.

[2] Savyed MRG, Sayadi MH. Variations in Heavy Metal Accumulations within the Surface Soils from the Chitgar Industrial Area of Tehran. Proceedings of the International Academy of Ecology and Environmental Sciences, 2011; 1(1): 36-46.

[3] Edokpayi JN, Odiyo JO, Olasoji JO, Assessment of heavy metals contamination of Dzindi River in Limpopo Province, South Africa International Journal of Natural Science Research. 2014; 2:185-194.

[4] Lalevic T, Raoicevic V, Kikovic D, Jovanovic L, Momirovic GS, Jovic I, Talaie AR, Morina F. Biodegradation of MTBE by bacteria isolated from oil hydrocarbons-contaminated environments. Int. J. Environ. Res. 2012; 6: 81-86.

[5] Avalon Global Research Report (2012). Water and waste water treatment opportunity in India. An overview. [Internet]. 2012 [cited 2018 July 20] Available from:www.export.gov.il/uploadfiles/02/2012/ indiawater.pdf?loaded $=$ true.

[6] Edokpayi JN. Assessment of the efficiency of wastewater treatment facilities and the impact of their effluent on surface water and sediments in Vhembe District, South Africa. Ph.D. Dissertation. University of Venda, 2016.

[7] Ridings MJ, Doick KJ, Martin FL, Jones KC, Sample KT. Chemical measures of bioavailability/bioaccessibility of PAHS in soil: Fundamental to application. Journal of Hazardous Materials, 2013; 261: 687-700.

[8] Ogamba EN, Izah SC, Oribu T. Water quality and proximate analysis of eichhorniacrassipes from River Nun Amassoma axis, Nigeria. Research Journal of Phytomedine. 2015; 1(1): 43-48.

[9] Monney I, Donkor EA, Buamah R. Clean vehicles, polluted waters: Empirical estimates of water consumption and pollution loads of the carwash industry. Heliyon. 2020; 6: 1-9.

[10] Lokhande RS, Singare PU, Pimple DS. Toxicity study of heavy metals pollutants in wastewater effluents samples collected from Taloja industries Estate of Mumbai India. Resource and Environment Journal. 2012; 1(1): 13-19

[11] Subodh S, Gusung DB, Bishal KS, Ram DT. Assessing the impacts of vehicle wash wastewater on surface water quality through physicochemical and bentic macro invertebrates analysis. Water Science. 2020; 34(1): 39-49.

[12] Baa-Poku J, Asante F, Amakye JS. Impact of urban effluents on the macro invertibraes of a creek in Accra, Ghana. West Africa J. Appl Ecol. 2013; 21: 97-109.

[13] Rai R, Sharma S, Gurung DB, Sitaula BK, Raut N. Assessment of environmental impacts of vehicle wash centres at Olakha. Thimpil Bhytan. International Research Journal of Environmental Sciences. 2018; 7: 1-10.

[14] Sato T, Qudir M, Yamamoto S, Endo T, Zahoor A. Global regional and country level need for data on wastewater generational treatment and use. Agricultural Water Management. 2013; 130: 1-13.

[15] Olukanni DO, Ducoste JJ. Optimization of waste stabilization pond design for developing nations using computational fluid dynamics. Ecological Engineering. 2011; 37(11): 1878-1888.

[16] Bariweni PA, Izonfuo WI, Amadi EN. Domestic waste levels and assessment of their current management strategies in Yenagoa metropolis. Global Journal of Environmental Science. 2002; 1(1): 1519.

[17] APHA, Standard Methods for the Examination of Water and Wastewater. $22^{\text {nd }}$ ed. American Public Health Association. 8001 Street, NW Washington DC. 2012.

[18] Priyanka S, Omkar S, Supriya S. Phytoremediation of industrial mine wastewater using water hyacinth. International Journal of Phytoremediation. 2017; 19(1): 87-96.

[19] Ademoroti CMO. Standard Methods for Water and Effluents Analysis. Foludex Press Ltd. Ibadan; 1996.

[20] Lu Q, He ZL, Grivetz DA, Stoffella PJ, Yang X. Uptake and distribution of metals by water lettuce (pistia stratiotes L). J. Environ. Sci. Poll. Res. 2011; 18: 978-986.

[21] Anima P, Kiriti A, Gopal P. Assessing the potentials of lemna minor in the treatment of domestic wastewater at pilot scale; environmental monitoring assessment. Spring Journal. 2012; 184: 4301-4307.

[22] Ugya AY. The efficiency of lemna minor in the phytoremediation Romi stream: A case study of Kaduna Refinery and Petrochemical Company polluted stream. Journal of Applied Biology and Biotechnology. 2015; 3(01): 11-14.
[23] Shah RA, Kumawat DM, Singh N, Wani KA. Water hyacinth (elchhornia crassipes) as a remediation tool for dye effluent pollution. Int.J. Sci. Nature. 2010; 1(2): 172-178.

[24] Abbas Z, Arooj F, Ali S, Zaheer IE, Rizwan M, Riaz MA Phytoremediation of landfill leachate waste contaminants through floating bed technique using water hyacinth and water lettuce. Int. J. Phytoremediation. 2019; 31: 1-12.

[25] Wickramasinghe S, Jayawardana CK. Potential of aquatic macrophytes e. crassipes, $p$. stratiotes and salviniamolesta in phytoremediation of textile wastewater. J. Water Secur. 2018; 4: 1-8.

[26] Dipu S, Kumar AA, Thanga VSG. Phytoremediation of dairy effluent by constructed wetland technolog. Environmentalist. 2011; 31: 263 278.

[27] Aremu AS, Ojoawo SO, Alade GA. Water hyacinth (E. Crassies) culture in Sewage: Nutrient removal and potential application of byeproducts. Transnational Journal of Science and Technology. 2012; 2. (7): 103-114.

[28] Ajibade FO, Adeniran KA, Egbuna CK. Phytoremediation efficiencies of water hyancith in removing heavy metals in domestic sewage: A case study of University of Ilorin, Nigeria. Int. J. Eng. and Sci (IJES). 2013; 2 I(12): 16-27.

[29] Sasmaz A, Dogan 1M, Sasmaz M. Removal of Cr., Ni and Co in the water of chromium mining area by using lemnagibbaL. and Lemna MinorL. Water Environ. J. 2016; 30: 235-242.

[30] Pundlik W, Krishnamurthy R, Varsadia M. Removal of dye effluent by different aquatic plants in Kadodara (Dst.Surat) region by rhizofiltration technique. Journal of Scientific Research in Pharmacy. 2013; 2(2): 1-5.

[31] Anandha V, Kalpana S. Performance analysis of nutrient removal in pond water using water hyacinth and azolla with papaya stem. Int. J. Eng. Technol (IRJET,) 2015; 2: 444-448.

[32] Forough M. Investigation of the influence of Ceratophyllum Demersum to refine diluted comport latex. J. Appl. Sci. Environ. Manage. 2011 15.(2): 371-374.

[33] Nayyef, M, Azeez-Amal A, Sabbar A. Efficeincy of duckweed (lemna minor 1) in phytotreatment of wastewater pollutant from Basrah oil refinery. Journal of Applied Phytotechnology in Environmental Sanitation. 2012; 1(4): 163-172.

[34] Arias A, Ramirez A, Fernandez V, Sanchez NE. The use of common duckweed (lemna minor) in the treatment of wastewater from the washing of sisal fiber (furcraeabedinghansil). Ingenieria $Y$ Competitividad. 2016; 18(2): 25-34.

[35] Chukwunonso OI, Fauziah SH, Redzwan G. The international of water hyacinth (elchlorniagassipes) as aquatic macrophage treatment system (Amars) in phytoremediation for palm oil mill effluent (POME). International Journal of Science, Basic and Applied Research. 2014; 13: 31-47.

[36] Aliveza V, Venkatraman KR, Youong HA. Effectiveness of domestic wastewater treatment using bio-hedge water hyacinth wetland system. Water, 2015; 7(1): 329-347. 